\title{
Recurrent fifth metatarsal stress fractures in a professional soccer player with hypoparathyroidism: a case report
}

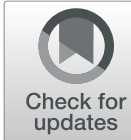

\author{
Itaru Kawashima ${ }^{1,2^{*}}$ (D), Atsushi Yamaga ${ }^{3}$, Ryosuke Kawai ${ }^{2}$, Yushi Hoshino ${ }^{2}$ and Shinya Ishizuka ${ }^{1}$
}

\begin{abstract}
Background: Hypoparathyroidism is characterized by low or inappropriately normal levels of parathyroid hormone leading to hypocalcemia. In this report, a case of recurrent fifth metatarsal stress fractures in a professional soccer player with hypoparathyroidism is presented.

Case presentation: A 23-year-old male professional soccer player developed left foot pain. He had no specific medical or family history. He was diagnosed with a fifth metatarsal stress fracture and underwent osteosynthesis with a cannulated cancellous screw 3 days after the injury. After three and a half months, the X-ray showed bone union, and he returned to full sports activity. However, he felt pain in his left foot again, and a re-fracture was found on X-ray a week later. Osteosynthesis was performed again. Two months after re-operation, the cause of refracture was investigated. Laboratory results showed abnormally low levels of serum calcium $(8.4 \mathrm{mg} / \mathrm{dL}$ ) and intact parathyroid hormone (i-PTH: $19.0 \mathrm{pg} / \mathrm{mL}$ ). However, other laboratory examinations were normal. Therefore, he was diagnosed with primary hypoparathyroidism according to the diagnostic criteria. Medical treatment was started with alfacalcidol $1.0 \mu \mathrm{g} / \mathrm{day}$. One month after starting medication, the serum calcium improved to $9.4 \mathrm{mg} / \mathrm{dL}$. Four months after the re-operation, the X-ray showed bone union, and he was therefore allowed to play soccer. While he played professional soccer, there were no new subjective complaints.
\end{abstract}

Conclusions: Hypoparathyroidism may be one of the risk factors for stress fractures. We believe that serum calcium levels should be checked in patients with stress fractures, and if the serum calcium is low, hypoparathyroidism should be considered.

Keywords: Fifth metatarsal stress fracture, Hypoparathyroidism, Hypocalcemia, Soccer, Case report

\section{Background}

Hypoparathyroidism is a rare metabolic disorder characterized by low or inappropriately normal levels of parathyroid hormone leading to hypocalcemia [1]. On the other hand, stress fracture of the fifth metatarsal bone is well described in the literature $[3,4,7,8,17]$. However,

\footnotetext{
* Correspondence: itaru.kawashima@gmail.com

'Department of Orthopaedic Surgery, Nagoya University Graduate School of Medicine, 65 Tsurumai, Showa-ku, Nagoya, Aichi 466-8550, Japan

${ }^{2}$ Department of Orthopaedic Surgery, Asahi University Hospital, 3-23 Hashimotocho, Gifu 500-8523, Japan

Full list of author information is available at the end of the article
}

re-fractures after fixation with a screw and completed healing have been mentioned significantly less often in previous studies [10].

A previous study showed that the prevalence of fragility fractures is greater in patients with hypoparathyroidism [5]. However, to the best of our knowledge, there are no previous reports of stress fractures with hypoparathyroidism. In this report, the case of a professional soccer player who had been twice treated surgically for left fifth metatarsal stress fractures and was diagnosed with hypoparathyroidism after re-fracture surgery is presented.

(c) The Author(s). 2020 Open Access This article is licensed under a Creative Commons Attribution 4.0 International License, which permits use, sharing, adaptation, distribution and reproduction in any medium or format, as long as you give appropriate credit to the original author(s) and the source, provide a link to the Creative Commons licence, and indicate if changes were made. The images or other third party material in this article are included in the article's Creative Commons licence, unless indicated otherwise in a credit line to the material. If material is not included in the article's Creative Commons licence and your intended use is not permitted by statutory regulation or exceeds the permitted use, you will need to obtain permission directly from the copyright holder. To view a copy of this licence, visit http://creativecommons.org/licenses/by/4.0/. The Creative Commons Public Domain Dedication waiver (http://creativecommons.org/publicdomain/zero/1.0/) applies to the data made available in this article, unless otherwise stated in a credit line to the data. 


\section{Case presentation}

A 23-year-old male professional soccer player visited our hospital because of left foot pain. He had had slight pain in his left foot while playing soccer 1 month before the visit and noticed severe pain a day before the visit, with no history of any injury or trauma. His height, weight, and BMI were $181 \mathrm{~cm}, 77 \mathrm{~kg}$, and $23.5 \mathrm{~kg} / \mathrm{m}^{2}$, respectively. He had no specific medical or family history. He had never smoked. He had never experienced paresthesiae, tetany, or convulsions. X-ray and computed tomography (CT) examinations showed a fifth metatarsal stress fracture. Three days after the onset of acute severe pain in his left foot, osteosynthesis with a cannulated cancellous screw with a diameter of $4.5 \mathrm{~mm}$ in the fifth metatarsal bone was performed.

He started jogging after two and a half months. After three and a half months, X-ray examination showed bone union, and he returned to play soccer without an orthosis. However, the patient felt pain and discomfort in his left foot with a sense of insecurity a week later. Three months and 3 weeks after the first operation, Xray examination showed re-fracture of his left fifth metatarsal, despite the screw fixation remaining in situ. Osteosynthesis was again performed, this time with a thicker headless compression screw. After the second operation, his ankle was immobilized with a brace for 2 weeks.

Two months after re-operation, the cause of the refracture was investigated. Laboratory results showed abnormally low levels of serum calcium $(8.4 \mathrm{mg} / \mathrm{dL}$, normal range $8.6-10.2 \mathrm{mg} / \mathrm{dL}$ ) and intact parathyroid hormone (i-PTH: $19.0 \mathrm{pg} / \mathrm{mL}, \quad 10-65 \mathrm{pg} / \mathrm{mL}$ ). Serum $25(\mathrm{OH}) \mathrm{D}$ was slightly low $(22 \mathrm{ng} / \mathrm{mL})$. However, other laboratory examinations, including serum phosphorus ( $4.2 \mathrm{mg} / \mathrm{dL}, 2.5-4.5 \mathrm{mg} / \mathrm{dL})$, serum magnesium $(1.8 \mathrm{mg} /$ $\mathrm{dL}, 1.2-2.2 \mathrm{mg} / \mathrm{dL})$, serum alkaline phosphatase $(161 \mathrm{U} /$ $\mathrm{L}, \quad 50-340 \mathrm{U} / \mathrm{L})$, serum creatinine $(0.91 \mathrm{mg} / \mathrm{dL}, 0.61-$ $1.04 \mathrm{mg} / \mathrm{dL})$, eGFR $\left(89.8 \mathrm{~mL} / \mathrm{min} / 1.73 \mathrm{~m}^{2},>60 \mathrm{~mL} / \mathrm{min} /\right.$ $\left.1.73 \mathrm{~m}^{2}\right)$, serum $1-25(\mathrm{OH})_{2} \mathrm{D}(42.5 \mathrm{pg} / \mathrm{mL}, 20-60 \mathrm{pg} /$ $\mathrm{mL})$, free T3 $(3.27 \mathrm{pg} / \mathrm{mL}, 2.3-4.3 \mathrm{pg} / \mathrm{mL})$, and free T4 (1.39 ng/dL, 0.9-1.7 ng/dL), were normal (Table 1). Bone mineral density (BMD) was very high using dual X-ray technology at $\mathrm{L} 2, \mathrm{~L} 3, \mathrm{~L} 4 .\left(1.474 \mathrm{~g} / \mathrm{cm}^{2}\right.$, T-score 2.4$)$ and the total hip $\left(1.698 \mathrm{~g} / \mathrm{cm}^{2}, \mathrm{~T}\right.$-score 5.8$)$. CT of the brain and neck was normal. The patient was diagnosed with primary hypoparathyroidism according to the diagnostic criteria, given the absence of other manifestations of endocrinopathy, acquired causative factors such as surgery, radiation therapy, infection, or any family history [9] (Fig. 1).

Medical treatment started with oral administration of alfacalcidol $1.0 \mu \mathrm{g} /$ day. One month after the start of treatment, the serum calcium improved to $9.4 \mathrm{mg} / \mathrm{dL}$. Xray examination showed bone union, and he was allowed to run (Fig. 2).

Four months after re-operation, the X-ray showed visible complete remodeling of the location of the re-fracture of the base of the fifth metatarsal bone, and he was

Table 1 Patient's laboratory results

\section{Laboratory results before and after treatment}

\begin{tabular}{|l|c|c|c|}
\hline & Baseline & After 1 months & After 3 months \\
\hline S-Calcium (8.6-10.2 mg/dL) & 8.4 & 9.4 & 9.0 \\
\hline S-Phosphorus $(2.5-4.5 \mathrm{mg} / \mathrm{dL})$ & 4.2 & 4.2 & 3.8 \\
\hline S-Magnesium $(1.2-2.2 \mathrm{mg} / \mathrm{dL})$ & 1.8 & & 2.2 \\
\hline S-Alkaline phosphatase $(50-340 \mathrm{U} / \mathrm{L})$ & 161 & 157 & 214 \\
\hline S-Creatinine $(0.61-1.04 \mathrm{mg} / \mathrm{dL})$ & 0.91 & 0.89 & 0.90 \\
\hline eGFR $\left(>60.0 \mathrm{~mL} / \mathrm{min} / 1.73 \mathrm{~m}^{2}\right)$ & 89.8 & 92.0 & 90.9 \\
\hline S-Albumine $(3.9-4.9 \mathrm{~g} / \mathrm{dL})$ & 4.4 & 4.7 & 4.6 \\
\hline S-iPTH $(10-65 \mathrm{pg} / \mathrm{mL})$ & 19 & & 28 \\
\hline S-25(OH) D ( ng/mL) & 22 & & 24.7 \\
\hline S-1-25(OH)2 D (20-60pg/mL) & 42.5 & & 83.7 \\
\hline 24-hour U-Calcium $(0.1-0.3 \mathrm{~g} /$ day) & 0.22 & & 0.04 \\
\hline 24-hour U-Creatinine $(1.0-2.0 \mathrm{~g} /$ day) & 2.8 & & 1.6 \\
\hline 24-hour U-Phosphorus $(0.50-2.00 \mathrm{~g} /$ day $)$ & 1.15 & & 0.84 \\
\hline
\end{tabular}




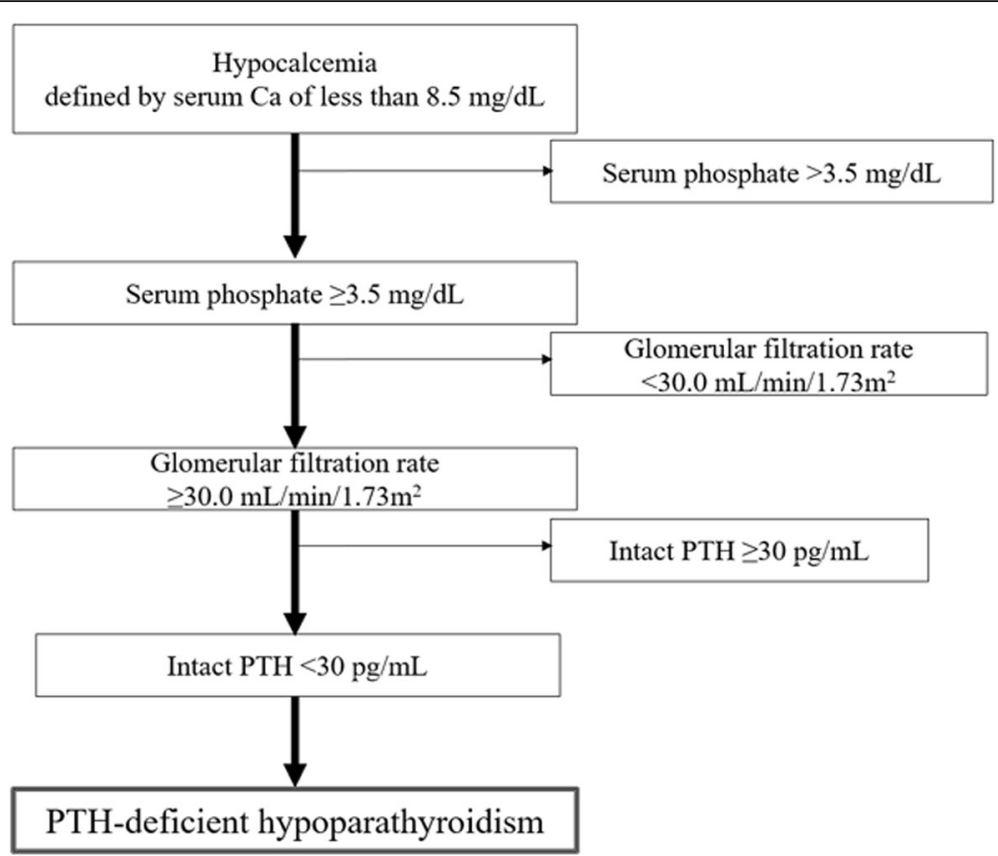

Fig. 1 Algorithm for evaluating patients with hypocalcemia and hypoparathyroidism. Figure based on information in Fukumoto et al. ${ }^{9}$

therefore allowed to play soccer. Five months after reoperation, laboratory results showed normal levels of serum calcium $(9.0 \mathrm{mg} / \mathrm{dL})$, i-PTH $(25.0 \mathrm{pg} / \mathrm{mL})$, serum $25(\mathrm{OH}) \mathrm{D}(30 \mathrm{ng} / \mathrm{mL})$, serum phosphorus $(3.8 \mathrm{mg} / \mathrm{dL})$, and serum magnesium $(2.2 \mathrm{mg} / \mathrm{dL})$. While he played professional soccer, there were no new subjective complaints related to the operated foot, and the X-ray of the foot taken at the last check was normal, with visible functional adaptation of the fifth metatarsal bone in his left foot.

\section{Discussion and conclusions}

A case of recurrent fifth metatarsal stress fractures with hypoparathyroidism in a professional soccer player was reported. In the present case, it was suspected that hypoparathyroidism was involved in the development of metatarsal stress re-fractures, in addition to the other multifactorial causes including screw fixation using small diameter screws or returning to play without an orthosis [18].

Previous reports showed that BMD is often above average in patients with hypoparathyroidism $[2,12,16]$. However, despite increased BMD, the risk of fragility fractures is higher in patients with hypoparathyroidism [5]. Furthermore, structural abnormalities of bone in such patients include increased cortical and trabecular width and cancellous bone volume, as well as markedly reduced bone turnover [14, 15].

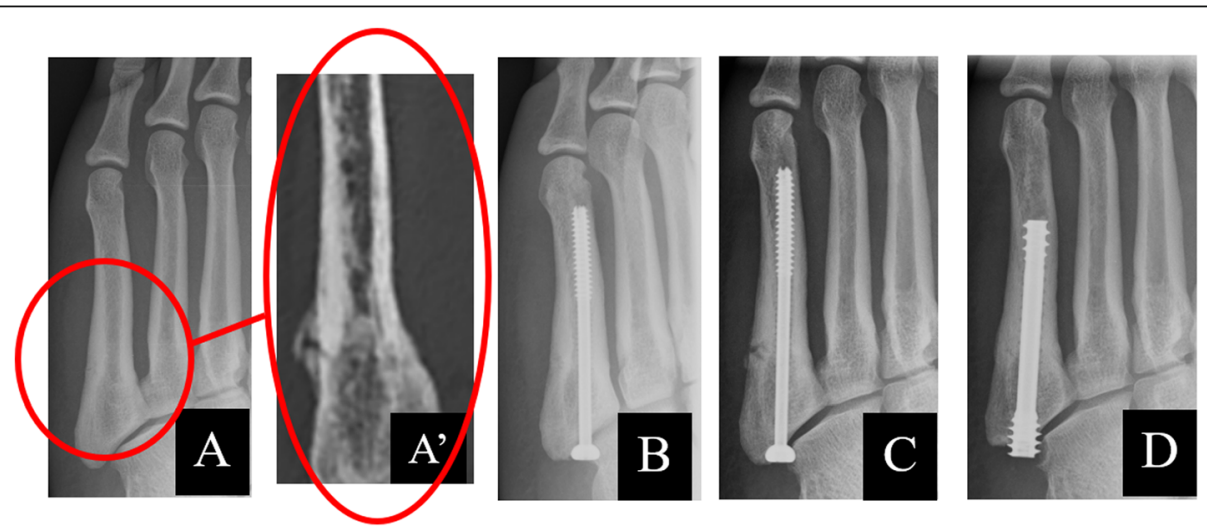

Fig. 2 a Radiographs of the left foot before the primary operation. (A') CT scan of the left foot before the primary operation. $\mathbf{b}$ Radiographs two months after the primary operation with a 4.5 -mm-diameter screw. c Radiographs showing the re-fracture 3.5 months after the primary operation. d Radiographs showing bone union 3 months after re-operation 
In the present case, the patient had an abnormally high BMD. The patient might have had a structural abnormality of bone, as in the previous reports. Deepak et al. showed that there are many risk factors for stress fractures, but hypoparathyroidism was not included [13]. However, this is the first case of recurrent stress fractures with hypoparathyroidism. Thus, hypoparathyroidism could also be a risk factor for stress fractures. Furthermore, in the present case, the patient had no symptoms of hypoparathyroidism, and there are numerous asymptomatic patients with the disease [11]. Therefore, there might be other patients with hypoparathyroidism who develop stress fractures. We believe that serum calcium levels should be checked in patients with stress fractures, and if the serum calcium level is low, serum i-PTH levels also need to be checked, since hypoparathyroidism should be considered.

Regarding treatment, there are no formal guidelines for the management of hypoparathyroidism [6]. It is true that previous reports showed the effectiveness of teriparatide. However, standard therapy of hypoparathyroidism is said to be vitamin $\mathrm{D}$ supplementation with the goal of maintaining serum calcium within the low-normal range and avoiding hypercalciuria [16]. Therefore, the present patient was treated with alfacalcidol because he had no symptoms other than the fifth metatarsal stress fracture. In the present case, the serum calcium level increased immediately after the start of alfacalcidol, and the patient could return to sports without any problem.

In conclusion, this is the first reported case of recurrent fifth metatarsal stress fractures with hypoparathyroidism. Hypoparathyroidism might be one of the risk factors for stress fractures, and there are many asymptomatic patients with the disease. Therefore, there might be patients with undiagnosed hypoparathyroidism who develop stress fractures. We believe that serum calcium levels need to be checked in patients with stress fractures, and if the serum calcium is low, serum i-PTH levels also need to be checked.

\section{Abbreviations \\ i-PTH: intact parathyroid hormone; BMD: Bone mineral density; \\ CT: Computed tomography}

\section{Acknowledgements}

Not applicable.

\section{Authors' contributions}

IK and AY were the principal clinicians who treated the patients. IK conceptualized and drafted the article. RK, YH and SI provided guidance for the literature search, the writing of the paper and also proof read the paper. All authors read and approved the final manuscript.

\section{Funding}

There was no funding for the research for this manuscript for the author.

\section{Availability of data and materials}

This is a case report of a single patient, to protect privacy and respect confidentiality; none of the raw data has been made available in any public repository. The original reports, laboratory studies, imaging studies and outpatient clinic records are retained as per normal procedure within the medical records of our institution.

Ethics approval and consent to participate

This report was approved by the institutional review board and ethics committee of Asahi University Hospital.

\section{Consent for publication}

The authors have obtained the patient's written informed consent for print and electronic publication of this case report.

\section{Competing interests}

The authors declares that they have no competing interests.

\section{Author details}

'Department of Orthopaedic Surgery, Nagoya University Graduate School of Medicine, 65 Tsurumai, Showa-ku, Nagoya, Aichi 466-8550, Japan.

${ }^{2}$ Department of Orthopaedic Surgery, Asahi University Hospital, 3-23 Hashimotocho, Gifu 500-8523, Japan. ${ }^{3}$ Department of Orthopaedic Surgery, Yamaga Orthopaedic Clinic, 9-15 Masagocho, Gifu 500-8864, Japan.

Received: 14 April 2020 Accepted: 29 May 2020

Published online: 03 June 2020

\section{References}

1. Abate EG, Clarke BL. Review of Hypoparathyroidism. Front Endocrinol (Lausanne). 2016;7:172

2. Bilezikian JP, Khan A, Potts JT Jr, et al. Hypoparathyroidism in the adult: epidemiology, diagnosis, pathophysiology, target-organ involvement, treatment, and challenges for future research. J Bone Miner Res. 2011;26:2317-37.

3. Boden BP, Osbahr DC. High-risk stress fractures: evaluation and treatment. J Am Acad Orthop Surg. 2000;8:344-53.

4. Brown $\mathrm{SR}$, Bennett $\mathrm{CH}$, Craig $\mathrm{H}$. Management of proximal fifth metatarsal fractures in the athlete. Curr Opin Orthop. 2005;16(2):95-9.

5. Chawla H, Saha S. Kandasamy, et al. vertebral fractures and bone mineral density in patients with idiopathic Hypoparathyroidism on long-term follow-up. J Clin Endocrinol Metab. 2017;102:251-8.

6. Cusano NE, Rubin MR, Irani D, Sliney J Jr, et al. Use of parathyroid hormone in hypoparathyroidism. J Endocrinol Investig. 2013;36:1121-7.

7. DeLee JC, Evans JP, Julian J. Stress fracture of the fifth metatarsal. Am J Sports Med. 1983;11:349-53.

8. Fujitaka K, Taniguchi A, Isomoto S, et al. Pathogenesis of fifth metatarsal fractures in college soccer players. Orthop J Sports Med. 2015;3:1-7.

9. Fukumoto S, Namba N, Ozono K, et al. Causes and differential diagnosis of hypocalcemia--recommendation proposed by expert panel supported by ministry of health, labour and welfare, Japan. Endocr J. 2008;55:787-94.

10. Granata JD, Berlet GC, Philbin TM, et al. Failed surgical Management of Acute Proximal Fifth Metatarsal (Jones) fractures: a retrospective case series and literature review. Foot Ankle Spec. 2015;8:454-9.

11. Michels TC, Kelly KM. Parathyroid disorders. Am Fam Physician. 2013;88:249-57.

12. Mitchell DM, Regan S, Cooley MR, et al. Long-term follow-up of patients with hypoparathyroidism. J Clin Endocrinol Metab. 2012;97:4507-14.

13. Patel DS, Roth M, Kapil N. Stress fractures: diagnosis, treatment, and prevention. Am Fam Physician. 2011;83:39-46.

14. Rubin MR, Dempster DW, Sliney J Jr, et al. PTH (1-84) administration reverses abnormal boneremodeling dynamics and structure in hypoparathyroidism. J Bone Miner Res. 2011;26:2727-36.

15. Rubin MR, Dempster DW, Zhou H, et al. Dynamic and structural properties of the skeleton in hypoparathyroidism. J Bone Miner Res. 2008;23:2018-24.

16. Shoback D. Clinical practice. Hypoparathyroidism. N Engl J Med. 2008;359:391-403.

17. Torg JS, Balduini FC, Zelko RR, et al. Fractures of the base of the fifth metatarsal distal to the tuberosity. Classification and guidelines for nonsurgical and surgical management. J Bone Joint Surg Am. 1984;66:209-14.

18. Wright WR, Fischer AD. Shively AR, et al Refracture of proximal fifth metatarsal (Jones) fracture after intramedullary screw fixation in athletes. Am J Sports Med. 2000;28:732-6.

\section{Publisher's Note}

Springer Nature remains neutral with regard to jurisdictional claims in published maps and institutional affiliations. 